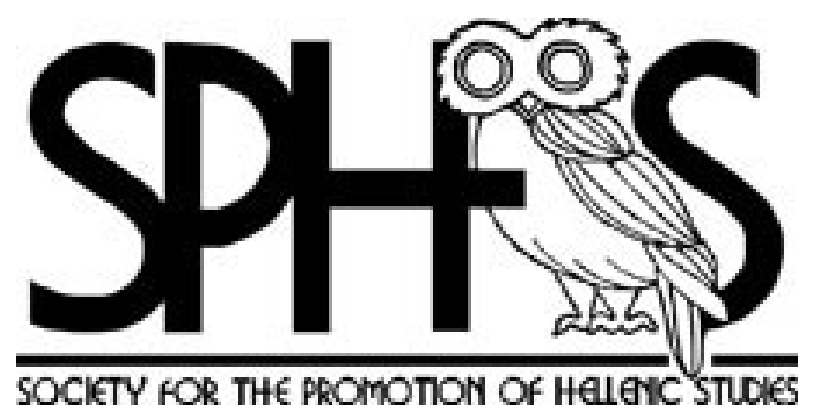

The Dedicated Ship of Antigonus Gonatas Author(s): W. W. Tarn

Source: The Journal of Hellenic Studies, Vol. 30 (1910), pp. 209-222

Published by: The Society for the Promotion of Hellenic Studies

Stable URL: http://www.jstor.org/stable/624300

Accessed: 23/12/2014 18:43

Your use of the JSTOR archive indicates your acceptance of the Terms \& Conditions of Use, available at http://www.jstor.org/page/info/about/policies/terms.jsp

JSTOR is a not-for-profit service that helps scholars, researchers, and students discover, use, and build upon a wide range of content in a trusted digital archive. We use information technology and tools to increase productivity and facilitate new forms of scholarship. For more information about JSTOR, please contact support@jstor.org.

The Society for the Promotion of Hellenic Studies is collaborating with JSTOR to digitize, preserve and extend access to The Journal of Hellenic Studies. 


\section{THE DEDICATED SHIP OF ANTIGONUS GONATAS.}

THIs paper is the sequel to one dealing with the chronology of the battles of Andros and Cos, published in the last number of this Journal : in it I propose to consider such information as we have about a great ship belonging to Antigonus Gonatas, which may throw some little additional light on these two battles. It is perhaps unnecessary to recall the fact that the third century B.C. was distinguished by a colossal series of experiments in the building of large warships, and that the limits of the effective history of these in action, so far as known to us, coincide pretty well (omitting Antony's revival) with those of the effective action of the Antigonid dynasty at sea: that is to say, ships larger than hexereis are not heard of in action earlier than the time of Antigonus I. or later than the time of Philip V. I make one assumption in this paper, if it be an assumption and not an axiom: I shall suppose that what is true alike of the earliest flint axes and of the modern battleship was true of the naval war-machines of the third century B.c., and that the advances made in building, dimly as we can distinguish them, were due, not to this or that chance or whim, but to a linked process of development.

\section{A.-'А}

Pollux i. 82. Pollux, enumerating here various sorts of warships, says as follows: '́като́

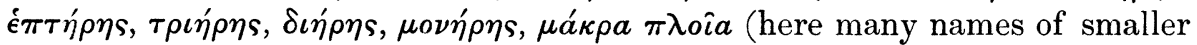

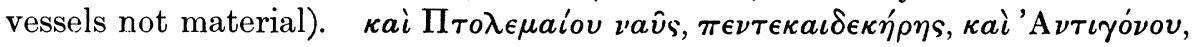

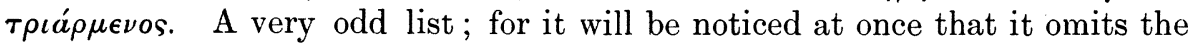
quinquereme, for so long the standard Roman battleship, the hexeres, so often the Roman flagship, ${ }^{1}$ the dekeres, Antony's sensation at Actium-all the Roman material, in fact. Pollux therefore is not giving a list of his own time at all: the substance of it is prae-Roman. Now Ptolemy Philadelphus

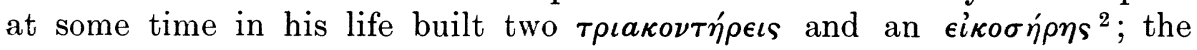
sentence then of this list referring to Ptolemy, which relates to some time

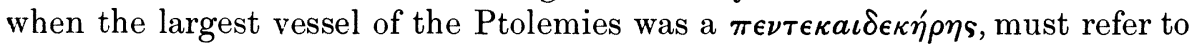

\footnotetext{
1 Both consuls at Ecnomus, Polyb. i. 26, 11 ; Scipio in 205, Livy xxix. 9; Sextus Pompey, App. b.c. v. 71 ; Oetavian in 36 , against
}

Sextus Pompey, and in 31 against Antony.

2 Dittenb. O.G.I. 39 ; Athen. v. 203 d. 
some period earlier than the building of these larger vessels by Philadelphus. This being so, we have here a list (whether copied by Pollux mediately or immediately), which in substance dates, not only from before the first appearance of Rome in the Eastern Mediterranean, but more precisely from some point in the reign of one of the two first Ptolemies.

Now the implied comparison of the ships of Ptolemy and Antigonus imports vessels more or less contemporary; and the culmination of the list with the ship of Antigonus shews that this ship was greater or more noteworthy than, or anyhow worthy to be compared with, that of Ptolemy. Which Antigonus is meant? As the list refers to a time not later than the

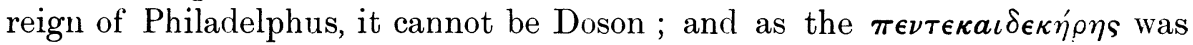

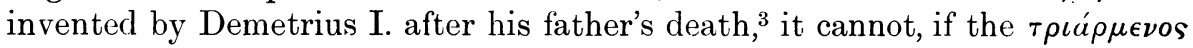
be an equally notable ship, be Monophthalmos. Moreover, there is hardly a place for so large a vessel belonging to Monophthalmos; for though he won one notable naval victory - that of Byzantium in 318 B.c.- this was before his shipbuilding of 315 , which seems to have been the first practical attempt to utilise very large vessels. ${ }^{4}$ Whether Diodorus be right or wrong in saying that he then built dekereis ${ }^{5}$ - and Demetrius had nothing larger than heptereis at Salamis in $306^{6}$-it is a far cry to a vessel fit to be compared

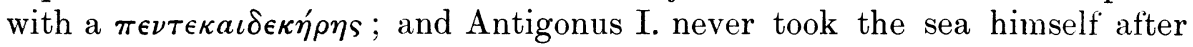
the siege of Tyre in 314 B.c. The Antigonus of our list is, therefore, certainly Gonatas.

I note two other points. Of ships larger than triremes, the list gives only heptereis and ennereis; and it was in these two classes of ships that the strength of the navy of Philadelphus is said to have consisted. ${ }^{7}$ This dates the list to his reign, rather than to the end of Ptolemy Soter's. The reason for building a number of heptereis is, obviously, the startling success of those

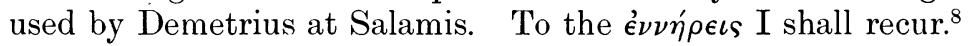

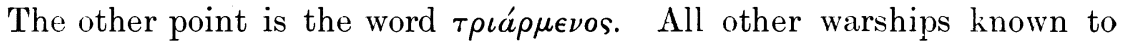
us from $\delta \iota \eta \rho \eta s$ upward bear names compounded of a numeral and the termination $-\eta \rho \eta s$, denoting in every case, by the increased numeral, what it is easiest to call increased horse-power,-i.e. an increase in the man-power per oar or per series of oars, whichever view we like to adopt. The word

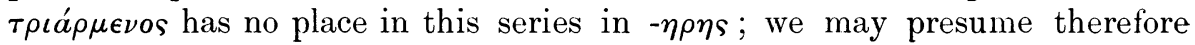
that the ship had no place in the series either: it was different or abnormal in some way.

The process of development of the $\tau \rho \iota \dot{\rho} \rho \mu \epsilon \nu o s$ shall be given as briefly as possible. After Demetrius had demonstrated, at Salamis, the capabilities of vessels greater than quinqueremes, the Hellenistic powers, in contra-

\footnotetext{
3 Plut. Dem. 43, in 289. In 301 Demetrius'

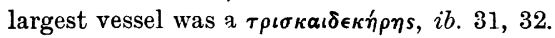

4 None are heard of earlier, and Ptolemy I. had nothing larger than quinqueremes at Salamis in 306 (Diod. $\mathrm{xx} .49,2$ ).

5 Diod. xix. 62, 7-9.

${ }^{6}$ Diod. xx. 50, $2 ; 52,1$.
}

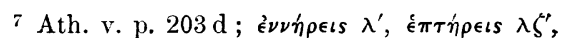
all the other numbers being far smaller. The actual numbers may be exaggerated, but the substance cannot be far wrong, seeing that the beginning of the catalogue has been confirmed by an inscription.

8 See n. 48. 
distinction to Rome, Carthage, and Rhodes, were all inclined to put their faith in the big ships. It is to be remembered that they were an Antigonid invention: Egypt only copied. ${ }^{9}$ Whatever else Demetrius was, he was a great sea-king; and through all vicissitudes of fortune, from 306 to his ultimate fall, he and his fleet controlled the Aegean as absolutely as it was possible to do with galleys. ${ }^{10}$ He built ships up to hekkaidekereis before his death. ${ }^{11}$

What Ptolemy Soter built we do not know ; but Lysimachus, Demetrius' most bitter enemy, asked and obtained leave to inspect the vessels of the latter, ${ }^{12}$ and with the result of this inspection we must connect the extra-

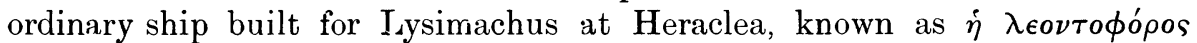

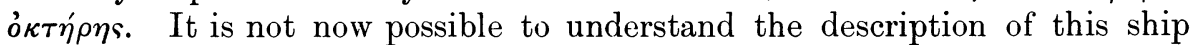
given by Memnon; but it is at any rate clear that it was a new or abnormal development of some sort, for it possessed more than one $\kappa a \tau a \sigma \tau \rho \omega \mu a$ or deck, ${ }^{13}$ whereas the series of galleys in $-\eta \rho \eta s$, even the largest, had only one. ${ }^{14}$ That it was not an ordinary octeres is further shewn by its great size and by the fact that it must have been an answer to Demetrius' $\tau \rho \iota \sigma \kappa a \iota \delta \epsilon \kappa \eta \rho \eta s^{15}$ if not to an even larger vessel; for as Lysimachus did not win Heraclea till 289, his octeres must have been built for use against Demetrius in the

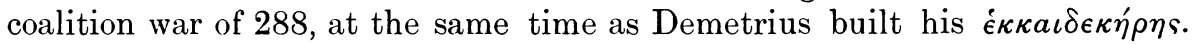
In 280 this great octeres was largely responsible for the very important ${ }^{16}$ defeat at sea which Gonatas suffered at the hands of Ptolemy Ceraunus, then in possession of Lysimachus' navy; - a defeat which ended for the time being any hope which Gonatas may have had of recovering the Aegean, and left Egypt (upon Ceraunus' death) supreme there for the next generation.

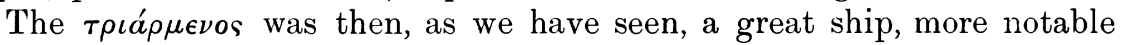

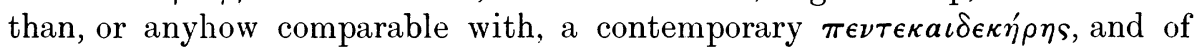

\footnotetext{
9 It might be more accurate to call them a Phoenician invention; for the first that we hear of (Antigonus in 315, Diod. xix. 58, 4; $62,7-9$ ), and the last that we hear of (fleet of Antiochus III. at Side, Livy xxxvii. 8, 3; 23,5 ), are alike built in Phoenicia.

10 Apart from the other evidence, the unexplained story in Plut. Dem. 25, that Demetrius' friends called the other kings mere officials of Antigonus and Demetrius, and (among them) nicknamed Agathocles his $\nu \eta \sigma \iota a ́ \rho \chi \eta s$, bears on this. This rare word (in the form $\nu \eta \sigma$ ía $\rho$ os) is found ouce in the fourth century (Antiphanes ap. Ath. viii. $342 \mathrm{e}$ ) in the plural, where it can hardly have a technical meaning; but a part from this, and from the imitation of Plutarch's story in Dion Cassius $(58,5)$, the word I believe only occurs in the well-known inscriptions of Philadelphus' reign referring to the nesiarch of the League of the Islanders, who seems to have been appointed by Ptolemy and not by the League (J. Delamarre, Rer. Phil.
}

xx. 111). Obviously, therefore, Demetrius' $\nu \eta \sigma i a \rho x o s$ can hardly have been anything but the nesiarch of the League, a valuable piece of evidence for the existence of the League, under Demetrius' control, in or about 303 в.c.

11 Plut. Dem. 43.

12 Plut. Dem. 20.

13 Memnon xiii. (F.H.G. iii. 534).

${ }^{14}$ For an ordinary octeres, Polyb. xvi. 3, 2. So Attalus' flagship at the kattle of Chios, Polyb. xvi. 6,6 ; the $\tau \epsilon \sigma \sigma \epsilon \rho \alpha \kappa \nu \tau \eta \dot{\eta} \eta \eta s$, Callixenus ap. Ath. v. 204 b.

10 Lysimachus' inspection of Demetrius' ships seems to belong to Demetrius' Cilician campaign of 300 or 299 (Beloch, Gr. Gesch. III. i. 221 , n. 5), at which time Demetrius' largest

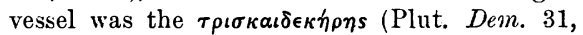

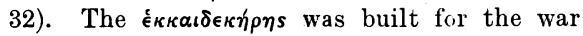
against the coalition (Plut. Dem. 43).

${ }_{16}$ Memmon xiv. can allude to Gonatas as

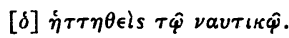


abnormal type. And one of the first events of Gonatas' reign was, as we have seen, the complete defeat of what remained to him of his father's navy by a fleet led by a great ship of abnormal type, itself probably the answer to

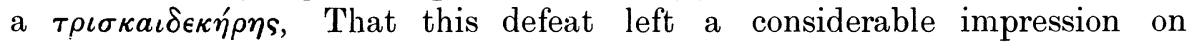
Antigonus goes without saying; and we are bound, I think, to see in the $\tau \rho \iota a ́ \rho \mu \epsilon \nu o s$ a development of the principle of (I can hardly say an answer to) Lysimachus' octeres.

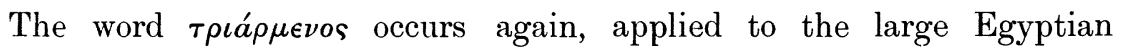
cornships of a later time. ${ }^{17}$ Mr. Cook thinks it means a three-decker; and if Antigonus' ship were modelled on that of Lysimachus, it would have been a

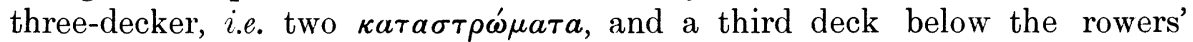
benches. ${ }^{18}$ The ship then may have represented, as against the ordinary galley, an attempt to gain height and stability, both for greater catapultrange at a distance and for advantage in fighting at close quarters. ${ }^{19}$

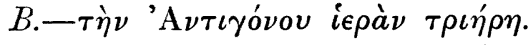

Moschion, ${ }^{20}$ after giving a long description of Hiero's ship the Syrakosia, compares with it, or rather declines to compare with it (which comes to the

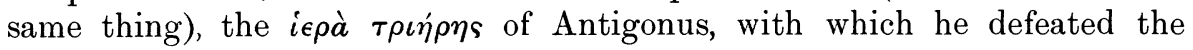
generals of Ptolemy off Leucolla in Cos, 'since he dedicated the ship to Apollo.' As Antigonus could not well fight in a ship that was already an $a^{\prime} \nu a^{\prime} \theta \eta \mu a$, it seems as if the only ${ }^{20 a}$ way of making anything of the last clause would be to suppose that the writer meant (but failed to express) that Antigonus had vowed the ship to Apollo in the event of victory, and dedicated it after, which is possible enough. The knot, however, has been cut by the universal adoption of Meineke's conjecture ö $\pi \circ v \delta \eta^{\prime}$. But history cannot be written by the aid of conjectural emendations; and all we can safely say of the text as it stands is, that the dedication of the ship was connected with the battle of Cos, that is, of course, that it took place after it.

With this very elementary consideration there vanishes the whole legend of the dedication of this ship at the Triopian sanctuary, a legend woven round Meineke's conjecture. ${ }^{21}$ In view, however, of the wide acceptance of both emendation and legend, I propose to consider them on their merits, before substituting what I believe to be the true version.

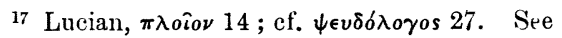
A. B. Cook, art. 'Ships,' in Whibley's Companion to Greck Studies, p. 485.

18 This last must follow as a matter of course, if the view that in their oarage these vessels were analogous to galleys a scaloccio, which I have taken (J.H.S. xxv. 1905, pp. 137, 204), be correct. See further n. 65 .

19 See n. 65.

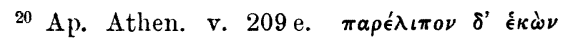

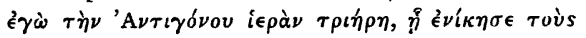

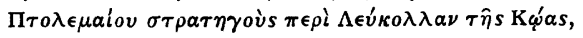

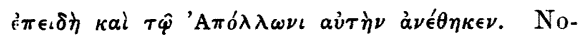
thing of course turns on the word $\tau \rho \iota \eta \dot{\eta} \eta$.

$20 \mathrm{a}$ It has been suggested to me, whether $\dot{\epsilon} \pi \epsilon \iota \delta\rangle$ ка' could mean 'when,' i.e. 'after which.' This is the sense one wants, but I do not know if it is possible. $\epsilon \epsilon \epsilon i \delta \dot{\eta} \gamma \epsilon \kappa \alpha \imath$ occurs Thuc. 6, 18, but in the sense of 'especially since.'

21 By Otto Benndorf in Conze, Hauser and Benndorf, Archaeoloyische Untersuchungen auf Samothrake, vol. ii. p. 84. 
The dedication of a warship, not taken from the enemy but one's own, is unique in Greek history. ${ }^{22}$ If, however, Antigonus desired to honour some god in this fashion, religion provided an appropriate deity; and if for some reason he found Poseidon, whom his father had delighted to honour, unsuitable, one would have expected his thoughts to have turned to Pan, the friendly patron who had already aided him in two of the chief victories of his career. $^{23}$ There must have been some quite overmastering reason for the selection of Apollo, a god in no way concerned with sea-fighting.

Now ötrov can only mean 'upon Cos.' But there is no reason, overmastering or other, for a dedication to Apollo upon Cos. The god of Cos was Asklepios; and Apollo, though worshipped there, counted relatively for so little, that he could be reckoned merely one of the 'other gods,' a mere $\sigma v^{\prime} \mu \beta \omega \mu o s$ or $\sigma v_{\nu \nu a o s}$ of the divine physician. ${ }^{24}$ In face of this, the fact that Cos appears somewhat later under Antigonid jurisdiction is hardly material..$^{25}$

It has been seen that Cos will not do; and the unfortunate ö $\pi 0 v$ has consequently been strained past all bearing in order to make it refer to the Triopian shrine on the mainland. The accepted view is, that the ship was dedicated to Apollo at this shrine, a view supported by references to a wellknown coin ${ }^{26}$ and a well-known epigram. ${ }^{27}$

The coin shews, on the obverse a head of Poseidon, his hair bound with a ' marine plant,' on the reverse Apollo seated on the prow of a ship. That the coin belongs to Gonatas, and commemorates the dedication of his ship to Apollo after Cos, I have no doubt; but it is difficult to follow Dr. ImhoofBlumer in bringing it into connexion with the Triopian festival. For this was not a festival in honour of Poseidon and Apollo, as Imhoof-Blumer states. Herodotus indeed mentions Apollo only, but in an informal way, ${ }^{28}$ and his statement is not necessarily inconsistent with other deities participating. But our only other authority, the Scholiast on Theocritus xvii., apparently quoting from Aristides, mentions in one place, as the deities in whose honour

22. There is only one instance even of the dedication of a complete vessel taken from the enemy, viz. after Salamis (Herod. viii.121). The practice was to dedicate the beaks only, or the a $\kappa \rho \omega \tau \dot{\eta} \rho \iota \alpha$; so in the Treasury of the Athenians at Delphi (Paus. x. 11, 5), and on the Roman coumnae rostratae; cf. the ships' beaks in the Delian inventories, and Dar. Sagl. Donarium.

${ }^{23}$ J.H.S xxix. pp. 273-4.

24 The inscription from $\mathrm{Cos}$ in honour of $\mathrm{Ce}$ phisophon (Dittenb. O.G.I. 42 ; see Herzog, Koische Forschungen und Funde, 1899, pp. 1-10) mentions a letter of Ptolemy II. to the people of Cos about some offerings which he

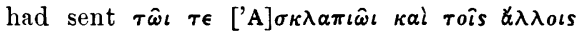
$\theta \in o$ is. Dr. Herzog points out that the $\sigma_{\lambda \lambda \lambda o \text { เ }}$ $\theta \in o l$ must be those who were $\sigma \dot{s} \mu \beta \omega \mu o l, \sigma u ́ \nu \nu a o l$, or $\sigma$ v́noเкo of Asklepios; and the list of these, known to us from Herondas iv. 1 seq., comprises Coronis, Apollo, Hygieia, Panace, Epio,

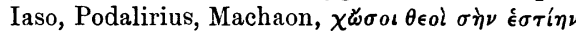
$\kappa \alpha \tau \sigma \iota \kappa \hat{\jmath} \sigma \iota \nu$.

${ }^{25}$ Paton and Hicks, xxxii. = Newton, $G r$. Inscr. in B.M. No. $247=$ Collitz-Bechtel, $3611=$ No. 6 in J. Delamarre, Rev. Phil. (1902) xxvi. 301 : attributed to Doson's reign.

26 Tetradrachm of Antigonus Gonatas; Imhoof-Blumer, Monnaies Grecques, 127 ; Head, H.N. 204 ; G. F. Hill, Historical Grcek Coins, 129.

27 Kaibel, Epigr. $781=$ Newton, Inscr. in B.M., Cnidus, Halicarnassus, Branchidae, No. 797. See Usener in Rhein. Mus. xxix. 1874, p. 36 .

28 Herod. i. 144. 
the $\dot{a} \gamma \dot{\omega} \nu$ was held, Poseidon and the Nymphs, ${ }^{29}$ in another, the Nymphs, Apollo, and Poseidon. ${ }^{30}$ There is no reason to doubt this, seeing that a further statement of the same writer, that the $\dot{a} \gamma \dot{\omega} \nu$ was called $\Delta \omega \omega_{\rho} \iota \mathbf{s}$, is confirmed by two inscriptions. ${ }^{31}$ It is possible that the ${ }^{3} \gamma \boldsymbol{\omega}^{\prime} \nu$ had changed its character since Herodotus wrote: it is more probable that Herodotus' notice is informal, and that Apollo had invaded an older sanctuary. But the coin agrees neither with Herodotus nor with Aristides : there is Poseidon, and there are no Nymphs. It has no connexion with Cnidus ${ }^{32}$ : from the monogram Imhoof-Blumer thought that the specimens which bear this monogram were struck at Demetrias in Magnesia.

But, apart from the coin, the Triopian sanctuary and festival, even if of some importance in the sixth century, had become a purely local affair. No inscriptions refer to it, so far as I know, except the two of Augustus' time already mentioned, where the games occur among other local or newlycreated games; and these may be a revival only, for Strabo in his description of Cnidus ${ }^{33}$ is silent as to games and sanctuary. It is mentioned once only in literature after Herodotus. ${ }^{34}$ Of the Dorian Pentapolis, three towns, Lindus, Ialysus, and Camirus, had become of little importance since the foundation of Rhodes; while a fourth, Cos, looked, as did Rhodes herself, not to Triopia but to Delos; it was to Apollo at Delos that the theoriai of these two cities, in the first half of the third century, went year by year. ${ }^{35}$ The festival must have sunk to a local appanage of the fifth city, Cnidus, in which shape it appears in the two inscriptions already cited. And the one important third century fact about it, that the Triopian sanctuary was honoured by Ptolemy Philadelphus, does not conflict with the view that it was of very subordinate importance; for Theocritus only assigns to it the same position in relation to Dorian Cos as Rheneia held in relation to Ionian Delos. $^{36}$

It is clear that we cannot here find the overmastering reas on which we require for a dedication to Apollo.

The real foundation for the view of the dedication which we are discussing is the epigram; and it ought to be abundantly clear that the theory which sees in the Antigonus of the epigram Antigonus Gonatasa theory already rejected by Beloch and Dittenberger-cannot be upheld. The epigram commemorates the shrine near Cnidus of a hero, Antigonus son

29 Schol. on Theocr. xvii. 61.

30 Do. on Theocr. xvii. 67.

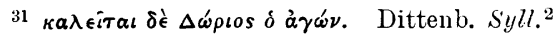

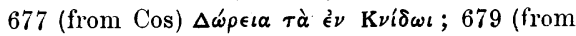
Halicarnassus) $\Delta \omega \rho l \epsilon \iota \alpha$ é $\gamma \mathrm{K} \nu$ í $\omega \iota$; both of Augustus' time.

32 That Prof. Bouché-Leclereq calls it a tetradrachm of Cuidus (Hist. des Layicice, i. 194) must be a mere slip of the pen.

33 Strabo. xiv. pp. $653,656$.

34 Theocr. xvii. 68.
35 See in particular the Delian inventories of Hypsocles' year (279 P.c. Homolle; B.C.H. xiv. 1890 , p. $389=$ Michel 833 ), and of Sosisthenes' ( 250 в.c. Homolle; B.C.H. xxvii. 1903, p. 62). The Coan theoriai have been collected by Herzog, op. cit. 153

36 Theocr. xvii. 68-70. H. von Prott in Rhein. Mus. 53, p. 476, has got this curiousiy upside down. The cult came to Philadelphus through his mother. See Appendix. 
of Epigonus, and his wife. ${ }^{37}$ Now while there is plenty of evidence that, from the middle of the third century onward, the second generation of rulers

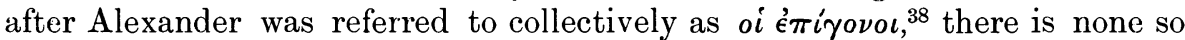
far as I know to shew that a single member of that generation, such as

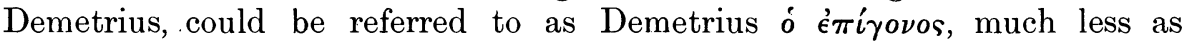
$o$ érírovos alone..$^{39}$ And even if it were possible, is it conceivable that the definite article could be omitted? Epigonus is quite a common name ${ }^{40}$ nevertheless, I suppose that if we found 'A century inscription, instead of (as it happens) in one of Commodus' time, ${ }^{41}$ some one would refer it to Antiochus Theos. In conclusion, I may make the obvious remark that a dozen shrines of Gonatas by name would have no bearing, one way or the other, on the question of the dedication of the ship. As a fact, however, we have no reason to suppose that Gonatas ever sought or obtained a footing upon the mainland.

I do not, however, like to leave Antigonus son of Epigonus without considering an alternative view which has been put forward, and which I think can be carried a little further. I have relegated this question to an appendix.

We can now return to the text of Athenaeus. An overmastering reason for dedicating a victorious warship to Apollo could, in Gonatas' case, arise in one way only: the Apollo must be the god of Delos. His object, which he in fact achieved, as shewn in my former paper, was the overthrow of the seapower of Egypt and the bringing back under the rule of his house of the League of the Islanders, whose headquarters Delos was, and of the Aegean whose sea-power Delos typified. Delos was the centre, material and symbolic, of that rule of the sea which Gonatas desired to re-establish. As the would-be king of Babylon kissed the hands of Bel, so he who aspired to admiralty in the Aegean brought his gifts to the Delian Apollo. It was in Delos, when won, that Gonatas set up the statues of his ancestors; and no more significant way of proclaiming to the world the defeat of Egypt and the re-establishment of Demetrius' sea-power could be devised than for the victor to dedicate his now useless vessel to the god of what had been the very centre and symbol of the Egyptian naval supremacy. At Delos, then, if anywhere, we may expect to find some trace of the dedicated ship.

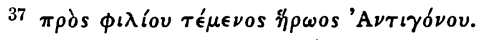

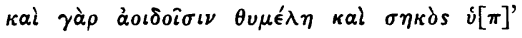
औrk $\gamma \in t$

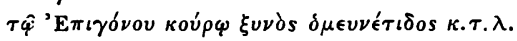

38 The title of the history of Nymphis of Heraclea (temp. Ptol. Euergetes I.), as given by

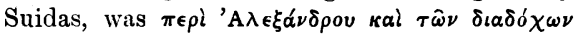
кal $\dot{\epsilon} \pi \imath \delta \delta \omega \nu$. Earlier still, the second part of the Historics of Hieronymus of Cardia, written about $260-250$ B.c., seems to have been called

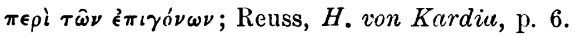
For later dates, Diod. i. 33 ; Strabo, xv. p. 736 ; Dionys. Hal. Ant. Rom. i. 6.
39 M. Holleaux' conjecture in the decree of the Telmessians in favour of Ptolemy, son of Lysimachus (B.C.H. 1904, p. $408=$ Dittenb.

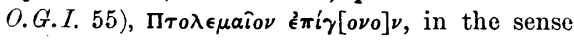
of 'son of the Diadochus Lysimachus,' is based expressly on this epigram, and seems open to precisely the same objections. If the missing word must be a surname, it may be one quite unknown to us; who, in similar circumstances, could have correctly restored 'Gonatas'?

${ }^{40}$ See e.g. Pauly-Wissowa, s. $v$. and the indices to $I . G$. xii.

${ }^{41}$ I.G. xii. 7, 247 :-from Minoa in Amorgus. 


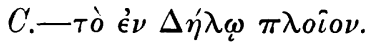

Pausanias, ${ }^{42}$ speaking of the Areopagus, says that near it is shewn the ship built for the Panathenaic procession. Some one, he thinks, may have surpassed (or conquered-the word $i \pi \epsilon \rho \epsilon \beta a ́ \lambda \epsilon \tau o$ is ambiguous), this vessel; then he adds, 'but I know that no one ever conquered the ship in Delos, which ...' The last seven words are untranslatable, as most of the material which might have supplied the key to their meaning is lost.

Why does Pausanias suddenly jump from the Areopagus to Delos, and why does he use the extraordinary word $\nu \iota \kappa \eta \sigma a \nu \tau a ?$

The most recent commentators on Pausanias, Dr. Frazer and Hitzig,

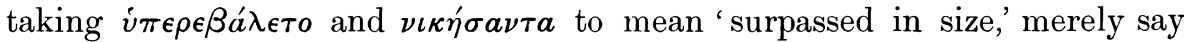
that Pausanias was mistaken and that there were bigger ships than an

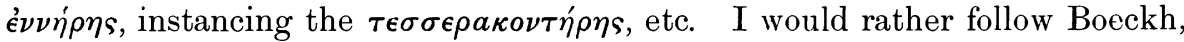
who pointed out that we must not attribute to Pausanias such elementary ignorance. ${ }^{43}$ Boeckh's own conjecture was that the Delos ship was a festival ship, like the Panathenaic only larger and sailing only on land. If there had been such a festival at Delos, we ought perhaps, among the mass of material available since Boeckh's day, to have heard something of it by now ; and this

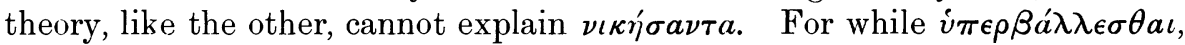
like our 'beat,' is ambiguous between the ideas of size and victory, $\nu \iota \kappa \hat{\alpha} \nu$ is (at least so far as I can find) not ambiguous; it is our 'conquer,' and Pausanias must have had a reason for using it. For if I want to say 'No one ever built a bigger ship than such and such a one,' I do not say 'No one ever conquered it.' Moreover, if anyone says, as Pausanias is supposed to do, 'Perhaps some one may have built a bigger ship than ship A,' followed immediately by the statement 'Ship B is the biggest ship that ever was in the world,' he seems to me to be talking nonsense; it seems to me wo be equivalent to saying 'Perhaps there is a bigger ship than ship A, but anyhow ship B is bigger,' which is surely a contradiction in terms. ${ }^{43 a}$ We must look therefore, I think, for an interpretation that does not rest upon the idea of size.

The first thing is to get the connexion of ideas. Pausanias has been speaking of the new ship built for the Panathenaic festival. Now the Panathenaic ship seems to have represented the ship of Theseus, ${ }^{44}$ the ship which was perpetually kept in repair, ${ }^{45}$ and sent with the sacred embassy to Delos ${ }^{46}$; and this Delian theoria had been for a while revived at Athens in Hadrian's time: we know of at least four theoriai going. ${ }^{47}$ Pausanias' mental process therefore travels naturally from the new

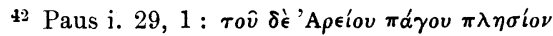

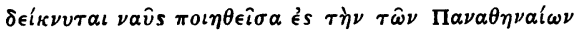

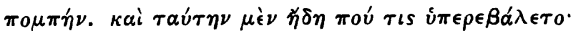

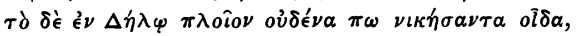

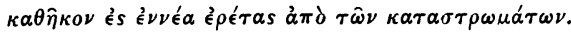
${ }^{43}$ Attisches Seewesen, p. 77.

43a Even if I am wrong on this point, it does not affect the argument that the Delos ship was that of Gonatas.

$\rightarrow$ C. Waldstein, Amer. Journ. Archacol.

i. pp. 10,15 ; see J. Harrison, Mythology and Monuments of Ancient Athens, 565.

45 Plut. Theseus 23 ; An seni sit resp. ger. 6.

46 Plato, Phacdo 58 A, B.

${ }^{47}$ G. Colin in B.C.H. xxiii. 85 ; von Schoeffer, Delos, in Panly-Wissowa, col. 2500. 
ship of the revived Panathenaea to the revived theoria sent to Delos, and this in turn reminds him of something which he knew, or which he had read about in some $\Delta \eta \lambda \iota a \kappa a^{\prime}$, concerning a ship at Delos.

Now in his description of the Delos ship, though we cannot translate it, two points clearly appear. It had some ninefold arrangement of rowers, and it had more than one $\kappa a \tau a ́ \sigma \tau \rho \omega \mu a$ : that is to say, it was some unusual or

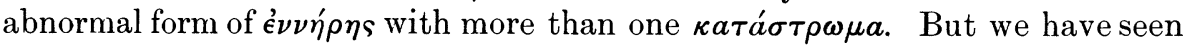
that the first great naval incident of Gonatas' reign was his defeat by a fleet

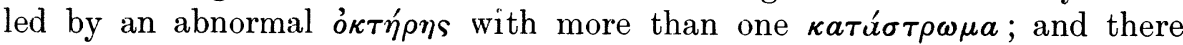
appeared every reason to suppose that his ship the $\tau \rho \iota \rho^{\prime} \rho \epsilon \iota \nu$, which from its

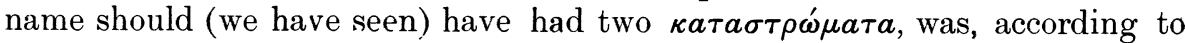
the law of continuous development, built with reference to the type of that

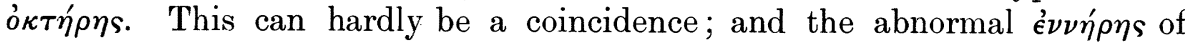

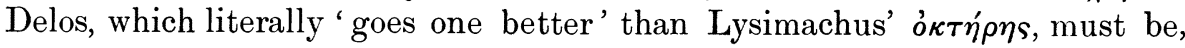

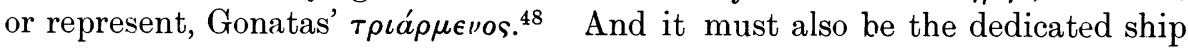
which we expected to find at Delos; for Gonatas can hardly have dedicated two great yessels there. Consequently, the ship which Pausanias knew of at

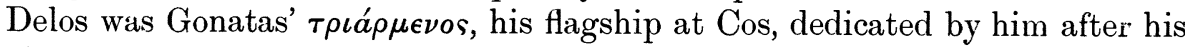
victory to Apollo at Delos.

The connexion of ideas in Pausanias' mind now becomes very plain. The Panathenaic ship represented the vessel of Theseus, dedicated on its return in triumph, moored near the Pythion,49 and (though for long

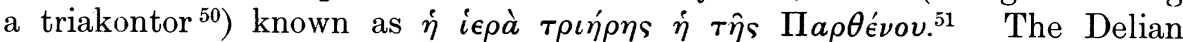
ship was, or represented, the vessel of Gonatas, dedicated after its triumph,

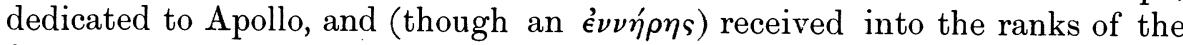

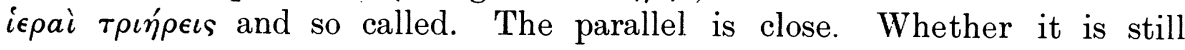
closer: whether Boeckh was right, and the Delos ship known to Pausanias was not in fact Gonatas' ship, but a copy of it, drawn on wheels at the Soteria or some other festival, after the fashion of the sacred ship of Smyrna which was carried round the market-place at the Dionysia to celebrate (so it was said) an old sea-victory of Smyrna over Chios ; ${ }^{52}$ - this we cannot decide.

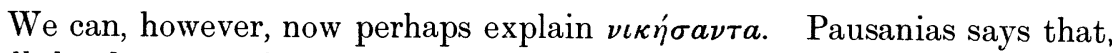
for all he knew to the contrary, some one somewhere might at sometime have had the better of Theseus' ship; but that he knew that no one had ever been victorious over the Delos ship. The original dedication then must have borne some such inscription as 'ever-victorious,' which Pausanias had either read or read of. The ship then had been victorious on more than one occasion; and as we know that its building must belong to the revival of

\footnotetext{
48 No doubt there is a relationship between

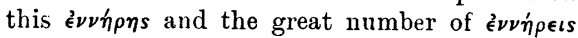
in Philadelphus' navy, just as his $\dot{\epsilon} \pi \tau \dot{\eta} \rho \epsilon \iota s$ must bear a relation to Demetrius' flagship at Salamis.

49 Philostratus, Vit. Soph. ii. $1,7$.

${ }_{50}$ Plut. Theseus 23. We are never expressly
}

told that it became a trireme. See Boeckh, Attisches Seewesen, p. 76 .

${ }^{51}$ Himerius, Or. iii. 12.

${ }^{52}$ Refs. in Frazer ad Paus. i. 29, 1. See, however, a totally different explanation of the Smyrna ship in Dr. Farnell's Cults of the Greek States, v. 192. 
Antigonus' navy at some time after the Chremonidean war (there being no other place for it), ${ }^{53}$ its 'victories' were in fact two, the battles of Andros and Cos: we know of no other possible. But the dedication of the ship to Apollo is expressly connected with the victory of Cos. This confirms the conclusion already arrived at in my former paper, that Cos must be later than Andros; consequently to Cos the Soteria, the festival of the 'crowning mercy,' is rightly assigned.

I promised before ${ }^{54}$ to explain the confusion which has led to our finding one and the same story told about both battles, a story which, even if true, can only have belonged to one of them. The explanation is now obvious. The story runs, ${ }^{55}$ that before the battle some one said to Antigonus, 'Do you not see how the enemy's ships outnumber ours?', to which he replied, 'Against how many of their ships do you set me?' Plutarch or his source took this remark to mean that Antigonus thought his personal presence was worth a number of vessels to his side-'one blast upon his bugle horn were worth a

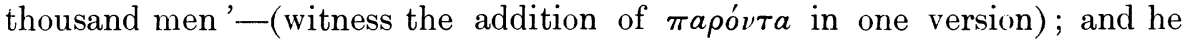
notes that such a thought was not in keeping with the character of Antigonus, who was no boaster. This explanation therefore will not do. Neither can we make a point out of the fact that Antigonus was there and Ptolemy was not ; for Ptolemy at the time was leading his land forces to victory, and a reflection on his absence from the fleet would have been impossible. The verbs employed both mean 'to range in order of battle against'; and the primary reference is to Antigonus' ship ; 'against how many ships do you range this of mine?' 'Me,' by a common figure of speech, imports 'my command.' Both battles then occurring in the same campaign, and Antigonus being present at both on the same flagship, nothing was more likely to happen at a later time than uncertainty as to which of the two battles could lay clain to an anecdote about that famous vessel. To which of the two battles it did in fact belong we cannot of course decide. ${ }^{56}$

\section{D.—ì 'A}

There still remains one question to consider : the Poseidon of Gonatas' tetradrachm.

Plutarch, after giving the story of Timoleon and the parsley to shew that

53 It cannot come before the war (J.H.S. xxix. 281); and it must come soon enough after to allow of Ptolemy II., before his death, building

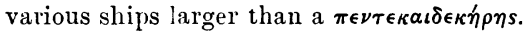

54 J.H.S. xxix. p. 267.

55 Plut. De seips. laudando, p. $545 \mathrm{~B}$ : 'A $\nu$ -

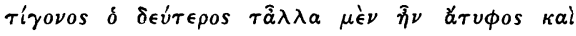

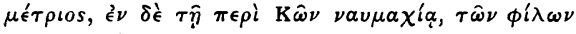

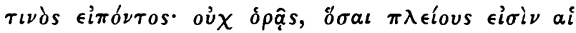

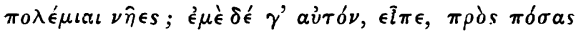
à $\nu \tau \imath \tau a ́ \tau \tau \epsilon \tau \epsilon$; Almost verbally repeated in Apophthegm. regum, p. $183 \mathrm{c}$, except that the $\kappa v \beta \epsilon \rho \nu \eta^{\prime} \tau$ s puts the question, and Antigonus

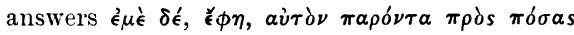

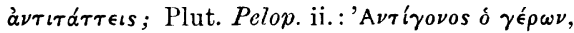

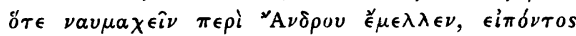

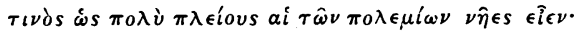

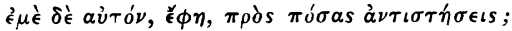

${ }_{56}$ I may remark here that the dedication of the ship at Delos shows, even more strongly than the building of the portico, that Gonatas expected no further trouble, and therefore confirms what I before deduced, that the war must have ended in a definite treaty, which gave him Delos and the Cyclades. 
parsley (and not pine) had once been the Isthmian wreath, adds 'and moreover Antigonus' flagship, whose poop spontaneously burst into leaf with parsley, got the to-name Isthmia.' ${ }^{57}$ This story is evidently meant to be on all fours with that of Timoleon. Now the point of the Timoleon story, as is well known, is, that parsley was the omen of death, that 'Timoleon's men on seeing it were cast down, and that he with great presence of mind recalled to them the fact that there was one Greek city where parsley meant, not death, but victory, and that for him therefore as a Corinthian it was a good omen. Obviously therefore, in the parallel story, since Antigonus himself was a Macedonian, the necessary Corinthian element can only have been supplied by the vava $\chi$ is and its crew : this flagship came from Corinth, and could have come from nowhere else.

Which Antigonus was it? Not Doson, for he never went to sea after regaining Corinth. Not Monophthalmos, for at the time of the only sea-fight which he fought and won in person (Byzantium, 318 B.c.) he had nothing to do with Corinth; neither apparently had his ally Cassander, seeing that in 313 Corinth was still in the hands of Polyperchon. ${ }^{53}$ In fact, the Antigonid connexion with Corinth begins first in $303,{ }^{59}$ only two years before the death of Monophthalmos, and at a time when he had long ceased to go to sea in person. The Antigonus in question is therefore Gonatas.

Corinth, like Athens, occupied a peculiar position in the composite realm of Gonatas, a position which, again like that of Athens, depended on sentiment no less than on facts. Of the naval arsenals of the EmpireDemetrias, Chalcis, Piraeus, Corinth-Corinth appears to have been the most important; and the reason for this, apart from facts such as the excellent harbours and docks, and the 'fetter' of the Acrocorinth, is to be found in the desire of Alexander's successors to attach themselves to him by any possible tic. If Ptolemy had his grave and name-city, Antigonus had something more than the home-land alone. Philip and Alexander had undertaken to conquer Persia as heads of a confederacy of Greek states formed at Corinth. When the first Antigonus and his son were attempting to reconstitute for themselves the undivided heritage of Alexander, Demetrius' first step was to revive the League of Corinth: ${ }^{60}$ it was, so to speak, the regularisation of his position. And Gonatas, holding Corinth in fact, held in idea the heritage of Alexander in Europe, the potential headship of the Greek world: he represented the men who had formed and reformed the League. It must have been a useful counter in the political game played between Antigonid and Lagid ; for although Ptolemy Soter's attempt to reconstitute the League in 308 under his own presidency had failed, ${ }^{61}$ the Lagids had not let slip the idea, witness the ceremony at the celebration of the Isolympic games in honour of Ptolemy Soter. There in the procession were borne together the statues

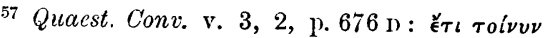

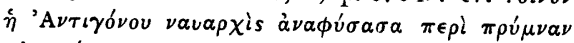

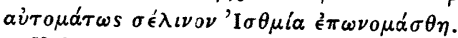

${ }_{58}$ Diod. xix. 74, 2.
}

59 Diod. xx. 103, 1 ; Plut. Dem. 25.

60 Plut. Dern. 25.

${ }^{61}$ Diod. xx. 37, 1-2; Suidas, Demetrius. See Beloch, Gr. Gesch. iii. 1, 150. 
of Alexander and Ptolemy Soter, and beside Soter stood the city of Corinth crowned with a diadem of gold, ${ }^{62}$ symbolic of the Corinthian League and the headship of the Greek world.

Gonatas then had a flagship built at Corinth, which won a victory: this is implied in the story. We only know of two naval victories of his, Andros and Cos; the ship therefore is identical with his ship dedicated at Delos, the $\tau \rho \iota \dot{\alpha} \rho \mu \epsilon \nu o s$. After one of these battles (whether the old king really loaded up with parsley ${ }^{63}$ or not) the ship got the name Isthmia in addition to its own name. Probably that name was Corinthia, for the following reason.

Moschion, we have seen, compares Gonatas' ship with Hiero's great vessel the Syrakosia, though the latter was far larger. The Syrakosia can hardly have been built before, or much before, the end of the first Punic war in 241 ; and a probable theory brings its presentation with a cargo of corn by Hiero to Egypt into connexion with the famine referred to in the decree of Canopus, a famine which took place somewhat earlier than the date of the decree (239/8 B.C.). ${ }^{64}$ Hiero's ship was not a galley, or primarily intended for war; she was a glorified round ship, though three-decked and armed like a floating fort; this furnishes a reason for supposing that the interpretation of $\tau \rho \iota a ́ \rho \mu \epsilon \nu o s$ as a vessel taller and heavier than the galley-type is correct. ${ }^{65}$ For Hiero's ship, by the law of development, did not spring out of nothing : her genesis must have been due, at least in part, to the tremendous renown

62 Ath. v. p. 201 d. Cf. J. Delamarre, Rev. Phil. xx. p. 114 ; J. Kaerst, Gesch. des hellenis tischen Zeitalters, II. i. p. 401.

${ }_{63}$ As there are a number of parallels between this ship and that of Theseus, we may wonder if this story has any connexion with the $\pi \rho \dot{v} \mu \nu \alpha$ $\dot{\epsilon} \sigma \tau \epsilon \mu \mu \epsilon^{\prime} \nu \eta$ of the latter when starting for Del s (Plato, Phaedo $58 \mathrm{~A}$ ). In the war against Philip V., in 199, the proconsul P. Sulpicius apparently copied Gonatas' 'omen' (Livy xxxii, 1,12 lauream in puppi navis longae enatim); but the sole and perhaps unexpected result was the decreeing of a supplicatio.

${ }^{64}$ Dittenb. O.G.I. s. 56, 1. 13 ; Niese ii. 196 ; Bouché-Leclercq, Hist. des Lagides, i. 253.

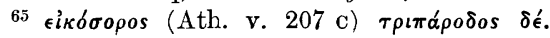

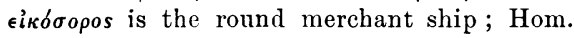

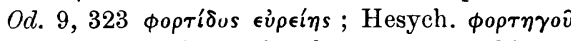
$\tau \epsilon \lambda \epsilon i ́$ s. No doubt it also meant a ship of twenty oars, as the lexicographers say, and see Pollux 1, 82 ; but the Syrakosia was not rowed

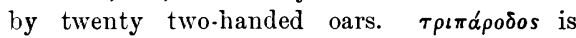
clealy shewn by the description (whatever $\pi \alpha$ óo os means elsewhere) to be used here for a three-decker. This supports the view that $\tau \rho \iota \dot{\alpha} \rho$ $\mu \epsilon$ vos means three-decker. We meet a round ship, armed and with a beak, in action against a galley, on a sixth century vase (Torr, Anc. Ships, Fig. 16). At a later time we have explicit mention of warships of a mixed type ; App. b.c. v. 95, Octavia presents her brother

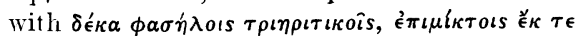

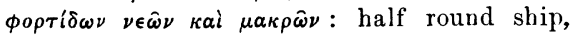
half galley. Such must have been the nature of Gonatas' ship ; on the one hand it was rowed, while Hiero's was not; on the other, it must have been of comparatively heavy tonnage, if timber enough for some fifteen quadriremes was built into it (Ath. v. $206 \mathrm{~F}$ compared with

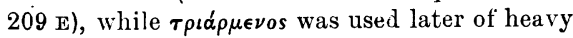
merchant vessels (u. 17). The extra height would be partly for the sake of catapult range (Ath. v. $208 \mathrm{C}$; , but also for fighting at close quarters; and the armanent of Hiero's ship, of which only the extra large catapult was Archimedes' invention, may well give a c'ue to that of Gonatas; towers, grapnels, and yards fitted for dropping stones on the enemy. It is conceivable that the $\dot{\epsilon} \kappa \kappa a \iota \delta \epsilon \kappa \eta \dot{\eta n s ~}$ of Philip V. (Liv. xxxiii. 30 inhabilis prope magnitudinis) was of this type carried to an extreme, and was by no means the

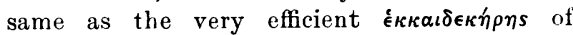
Demetrius I. (Plut. D $\mathrm{cm}$. 43). Gonatas may have beaten Egypt by much the same methods as Rome, getting Corintho-Macedonian ideas through Sicily, employed against Carthage in the first Punic war. 
of Gonatas' ship-(a renown we have been collecting scrap by scrap from our hopelessly mutilated tradition) - which she was intended to surpass. A naval architect, Archias, was sent for from Corinth to build her-possibly

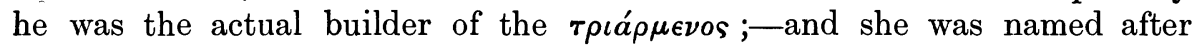
Hiero's city, Corinth's daughter-town. Her exemplar then can hardly have been called anything but Corinthia. For the parallel of the two ships lasted even to a change of name : as the Corinthia was renamed Isthmia after the Isthmian festival, so Hiero, when he sent the Syrakosia to Egypt, renamed her Alexandris. ${ }^{66}$

To return to the coin. The Apollo on the prow is, we have seen, Apollo of Delos. The Poseidon, his head wreathed with a 'marine plant,' must be Poseidon of the Isthmus; for we find Poseidon, his head similarly wreathed with a 'marine plant,' on copper coins of Corinth ${ }^{67}$ and the coincidence can hardly be unintentional. ${ }^{68}$ Whether the 'marine plant' can possibly represent the Isthmian parsley I must leave to others to say. But we may suppose, if we will, that Poseidon himself stood, then as later, on the mole of the harbour of Cenchreae, ${ }^{69}$ and thence surveyed the launch of the Corinthia; and I take it that the famous coin celebrates, so to speak, the life history of this ship; Poseidon, its birth at Corinth and its winning of the Isthmian name; Apollo, its victorious end at Delos.

\section{APPENDIX.}

Antigonus son of Epigonus.

In the Delian inventory of Demares' year (B.C.H. 6, 1882, p. $1=$ Dittenb. Syll. $^{2} 588$ ), 1. 94 appear two phialai, dedicated together under the hieropes of nine years before $=189$ в.c. (Homolle), by Ptolemy son of Lysimachus and Antipater son of Epigonus. From the conjunction of the gifts, Dittenberger thought that the latter donor, like the former, should be of royal race, of the house of some successor of Alexander, but pointed out that the name Epigonus is not known in any such house. He suggested, however, that Antipater might be a brother of our Antigonus son of Epigonus (whose date is unknown). Can one take the matter a little further?

Antigonus son of Epigonus appears as one who cultivated ( $\phi \iota \lambda i o v)$ the Triopian festival. We know of one family, and one only, which did this, that of Berenice the

66 Though this is the feminine of 'A $\lambda \epsilon \xi \alpha \nu \delta \rho \epsilon v^{\prime}$ (Etym. Mag. 389, 15), may it not refer to the festival of Alexander's worship rather than to the city?

67 Head, H.N. p. 339 ; period circ. B.c. 338-243. Dr. Head himself gives the comparison. The same type of Poseidon appears on other coins of Gonatas (Head, H.N. 203, 204): in the case of the Isthmian Poseidon this is only to be expected.

68 The resemblance to the coins of Corinth seems to me to dispose of several alternative views, such as : (a) that Poseidon can refer to

H.S.-VOL. XXX.
Triopia ; $(b)$ or to Delos, where his worship was active, including perhaps (F. Dürrbach in B.C.H. 1905, p. 524, No. 179, 1. 10) a naval sham fight at the Poseideia ; $(c)$ or is merely a reminiscence of Demetrius' coinage after Salamis, typifying naval victory in general : if indeed Demetrius' Poseidon of the second series (Head, Fig. 144) do not refer to the Isthmian congress, one of the fruits of victory, as much as to the victory itself.

69 Paus. ii. 2, 3. The statue actually seen by Pausanias may have replaced one there before the destruction of Corinth. 
second wife of Ptolemy Soter : she was (Schol. Theocr. 17, 61) daughter of an Antigone who was daughter of a Cassander who was brother of one Antipater, who cultivated the Triopian festival. [Not Cassander the king, on the dates; Beloch, Gr. Gesch. III. 2, 128.] We have here a family which inoluded both the names we require, Antigonus (in the form Antigone; so also Berenice's daughter) and Antipater; while two of its members, Antipater and Ptolemy Philadelphus, are the only people we know, other than our Antigonus, who were devotees of the Triopian cult.

Ptolemy son of Lysimachus has a tremendous literature of his own ; references and theories collected by M. Holleaux, B.C.H. 28, 1904, p. 408. Probably there were two of him ; but the point here is (and I need go no further), that on every theory yet put. rorward the Ptolemy so designated in Demares' list must be (or rank as) a descendant of Berenice through Arsinoe Philadelphus. If then we conjecture that the two sons of Epigonus (who need not belong to the same generation at all) belonged to Berenice's house, we see, not only that the two donors of 189 в.c. (rather perhaps 188) were a kind of relations, but that their connexion with the royal house of Egypt fits in well with the occasion : their offering can hardly have been anything but a complinent to Rome, the friend of Egypt, who had just definitely become mistress of the Aegean. It is perhaps a fair conjecture, from the occurrence in each case of the rare name Cassander together with Antipater, that Berenice's family was a collateral of that of Antipater the regent, and that she was therefore Eurydice's 'cousin' as well as maid of honour.

It is obvious that the conjecture that Antigonus son of Epigonus was a member of Berenice's house can be nothing but a conjecture, till we can prove the name Epigonus in that house. I have failed to see any satisfactory way of bringing it into relation with M. Holleaux' before-mentioned reading $\Pi \tau \sigma \lambda \epsilon \mu a \hat{\imath} o \nu \dot{\epsilon}^{\prime} \pi \dot{\gamma} \gamma[0 \nu 0] \nu$ in the decree of the Telmessians in favour of Ptolemy son of Lysimachus.

\section{A Correction.}

M. Schulhof has pointed out to me that in making the Theuergesia date from the archonship of Mantitheos ( $\$ \mathrm{E}$ of my former paper) I have misunderstood him, and I take the earliest opportunity of correcting this error, which I much regret. His reference in fact was to the third Ptolemaieia : the commencement of the Theuergesia is unknown. (I may add that a new inscription-Archiv für Papyrusforschung vol. 5 (1909), p. 158, No. 2-seems to show that Ptolemy III. did not acquire his cult-name till some little time after his accession.) This being so, the question of the precise date of the accession of Ptolemy III. only creates a difficulty if the third Ptolemaieia are the accession foundation of this monarch. I think they will turn out to be this, on the analogy of the first Ptolemaieia and the Demetrieia ; but they may of course fall in the reign of Ptolemy II., and this possibility may remove the objection to my suggested dating, which I thought I had to consider, viz.:- the possibility of Mantitheos' year falling before the actual accession of Ptolemy III.

W. W. TARN. 